\title{
High-resolution mapping of single neurons provides insight into neuron structure and LFP generation
}

\author{
Patrick Dini ${ }^{1,2,3^{*}}$, Maxime Ambard ${ }^{1}$, Ulrich Egert ${ }^{1,3}$, Urs Frey $^{4}$, Andreas Hierlemann ${ }^{4}$ \\ From Twentieth Annual Computational Neuroscience Meeting: CNS*2011 \\ Stockholm, Sweden. 23-28 July 2011
}

Recent modeling [1] has suggested that the spatial structure of single neurons, especially the orientation and the shape of their dendritic trees, is of great importance in the understanding of the properties of the LFP generated (for example, a low-pass filtering effect has been shown in remote neurites [2]). In order to test these predictions, high-density microelectrode arrays (MEAs) featuring 11'011 electrodes are a valuable tool [3]. They provide detailed information about the external electrical field potentials of cultured neurons, from which the relevant information about single neurons properties must be extracted. We developed an on-line software allowing us to track neurites of single neurons (Figure 1A-K, footprint of a neuron), which provides information about their spatial structure and their activity dynamics leading to predictions on their morphology (Figure 1L). These allow us to elucidate additional properties of LFP generation, such as, multi-polar potentials

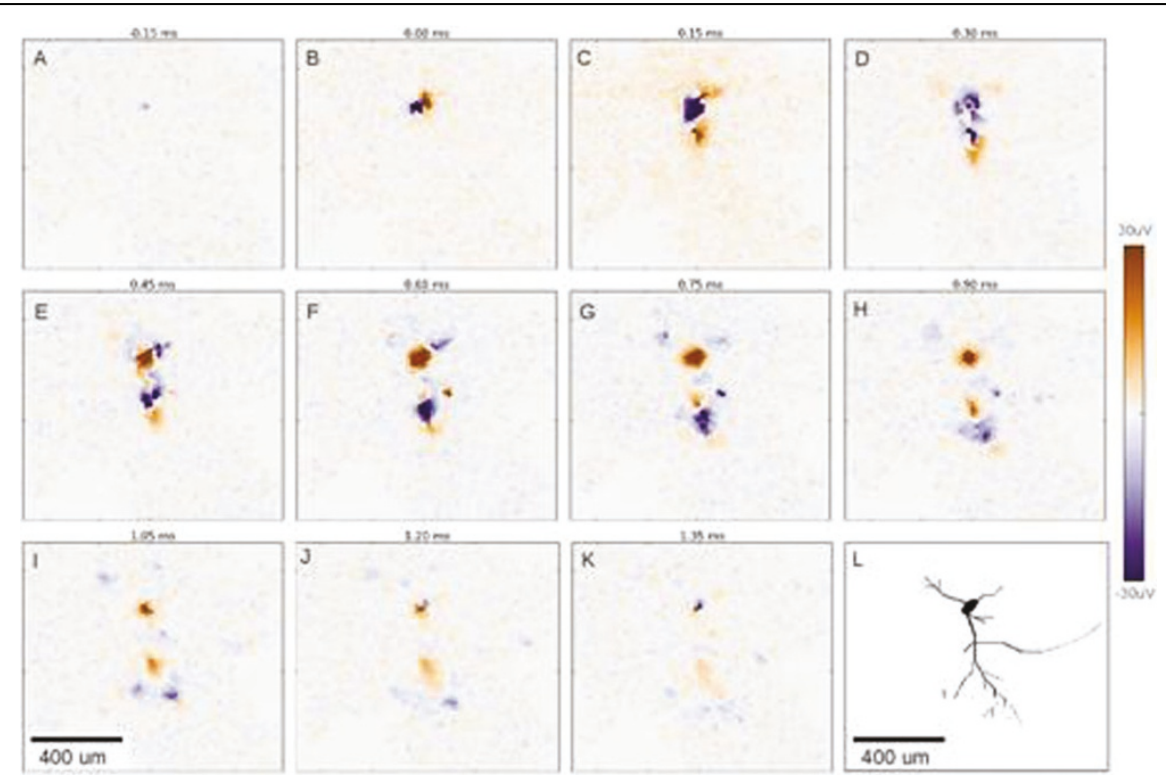

Figure 1

\footnotetext{
* Correspondence: patrick.dini@bcf.uni-freiburg.de

'Bernstein Center Freiburg, Albert-Ludwigs-University Freiburg, Freiburg

79100, Germany

Full list of author information is available at the end of the article
}

(C) 2011 Dini et al; licensee BioMed Central Ltd. This is an open access article distributed under the terms of the Creative Commons 
related to the morphology of the studied cell. Moreover, reconstruction of the morphology of different cells was performed based on footprints and compared with imaging from GFP-stained neural cultures.

\section{Acknowledgments}

The group of the Prof. Hierlemann for providing the MEAs and the support. Funded by the German BMBF (FKZ 01GQ0420 \& FKZ 01GQ0830) and by the EC (NEURO, No. 12788)

\section{Author details}

'Bernstein Center Freiburg, Albert-Ludwigs-University Freiburg, Freiburg 79100, Germany. ${ }^{2}$ Institute of Biology III, Albert-Ludwigs-University Freiburg, Freiburg 79100, Germany. ${ }^{3}$ Biomicrotechnology, Department of Microsystems Engineering, Albert-Ludwigs-University Freiburg, Freiburg 79100, Germany.

${ }^{4}$ Bio Engineering Laboratory, Department of Biosystems Science and

Engineering, ETH Zurich, Basel 4058, Switzerland.

Published: 18 July 2011

\section{References}

1. Einevoll GT, Wojcik DK, Destexhe A: Modeling extracellular potentials. J Comput Neurosci 2010, 29(3):367-9.

2. Linden $H$, Pettersen $\mathrm{KH}$, Einevoll GT: Intrinsic dendritic filtering gives lowpass power spectra of local field potentials. J Comput Neurosci 2010 29(3):423-44, Epub 2010 May 26.

3. Frey U, Egert U, Heer F, Hafizovic S, Hierlemann A: Microelectronic system for high-resolution mapping of extracellular electric fields applied to brain slices. Biosens Bioelectron 2009, 24(7):2191-8.

\section{Submit your next manuscript to BioMed Central} and take full advantage of:

- Convenient online submission

- Thorough peer review

- No space constraints or color figure charges

- Immediate publication on acceptance

- Inclusion in PubMed, CAS, Scopus and Google Scholar

- Research which is freely available for redistribution

Submit your manuscript at www.biomedcentral.com/submit
(Ciomed Central 